\title{
Museums and city aestheticization policies: controversies between the touristification of public spaces and the social role of museological institutions
}

Les musées et les politiques d'esthétisation des musées et des villes: controverses entre la touristification des espaces publics et le rôle social des institutions muséales

\section{Karla Estelita Godoy and Sarah Borges Luna}

\section{(2) OpenEdition}

\section{Journals}

Electronic version

URL: http://journals.openedition.org/iss/959

DOI: $10.4000 /$ iss.959

ISSN: 2306-4161

\section{Publisher}

ICOM - International Council of Museums

\section{Printed version}

Date of publication: 15 October 2018

Number of pages: $99-112$

ISBN: 978-92-9012-445-0

ISSN: 2309-1290

Electronic reference

Karla Estelita Godoy and Sarah Borges Luna, « Museums and city aestheticization policies: controversies between the touristification of public spaces and the social role of museological institutions », ICOFOM Study Series [Online], 46 | 2018, Online since 15 October 2018, connection on 23 October 2019. URL : http://journals.openedition.org/iss/959 ; DOI : 10.4000/iss.959 


\section{The Origins of
Puritan Politics in US Museums \\ Nation Building and "The Arts" from 1776 to 1806}

\section{Sheila K. Hoffman}

Curcom, Chair of Subcommittee on Ethics; University of Massachusetts, Lowell, Massachusetts, USA

Established in 1776 by a Declaration of Independence from England, the early United States was in a unique cultural position. Much of what was considered art in Europe was condemned under religious moral codes and revolutionary fervor. Meanuhile the spirit of the Enlightenment encouraged the emerging nation to raise itself through scientific exploration, one of the most famous being the Lewis \& Clark Expedition from 1804-1806. In this thirty-year period, the heady, sometimes volatile, combination of righteous morality and new-found power would forever mark the attitude towards "arts" in the United States and contribute to a unique iteration of museums and their practice. Using the first American science museum and art gallery, the Peale Museum, as a departure point, this paper explores the cultural environment of the early US to provide better insight on how early US religious attitudes continue to impact American museums. From modes of portraiture and the theater ban to the "Noble Savage", these historical factors 
reveal a unique and complex foundation that continues to impact the nature of US museums.

Key words: Museum, Art, U.S. History, Puritan, Peale.

\section{R'́s U Ḿ}

\section{Les origines de la politique puritaine des musées américains : la construction de la nation et « les Arts » de 1776 à 1806}

Fondés en 1776 à la suite de leur déclaration d'Indépendance vis-à-vis de la Grande Bretagne, les États-Unis occupent durant ces premières années une position culturelle unique. Les codes moraux et religieux, aussi bien que la ferveur révolutionnaire, condamnent à cette époque l'art Européen. En même temps, l'esprit des Lumières encourage la nation émergeante à se développer par le biais de l'exploration scientifique, ce dont témoigne l’Expédition Lewis et Clark de 1804 à 1806. Pendant cette période, la combinaison puissante et parfois versatile de la religion et du nouveau pouvoir marque fortement la définition des arts aux États-Unis, tout en contribuant à l'unicité des musées américains. Le premier musée de science et des beaux-arts aux ÉtatsUnis, le Peale Museum, constitue le point de départ de cet article qui montre comment l'environnement culturel de la jeune nation imprègne encore le modèle actuel. Qu'il s'agisse du regard religieux sur le portrait et de l'interdiction du théâtre ou du concept du " noble sauvage ", ces facteurs historiques continuent d'influencer les musées américains.

Mots clés : Musée, Art, Histoire des États-Unis, Charles Willson Peale

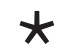

In the thirty-year period between the Declaration of Independence in 1776 and the Lewis \& Clark Expedition from I804-I806, the early United States found itself in a unique cultural position. A new citizenry outwardly shunned Great Britain and its culture as a souvenir of imperial occupation. Primarily Protestant, the former colonies also reviled more broadly European culture as a product of the sinful ostentation of the Catholic Church. Moreover, to a rebel nation impoverished by war, resources were too scarce to encourage or support the arts, especially when they had already been deemed frivolous, traitorous or immoral. And yet, it soon became apparent that the establishment of the United States as an independent country also required the formation of a national identity and thus, culture. How was such a feat accomplished under political, economic, and religious duress? 
While the arts were branded as frivolous pursuits of wealthy, hedonist Europeans, science seemed the key to prosperity through the capitalization of abundant natural resources as well as to the legitimation of the intellectual reputation of the new country. Principles of the Enlightenment, resonant among many "Founding Fathers", encouraged the new nation to raise itself through expanded knowledge and power. Education became the justification for rational museum entertainment. "Noble Savages" were positioned at the bottom of a new American mythology. And funding would be consistently dependent on popular appeal. In this new society, the heady sometimes volatile combination of righteous morality and new-found power would forever mark the attitude towards "arts" in the United States and contribute to a unique evolution of museums and their practice.

\section{Collecting in the Colonies}

The first colonies of North America possessed neither public museums nor libraries. The cost of importing objects from Europe and the necessity of concentrating on survival in the early American colonies limited the scope of private collections by placing value on the usefulness of things. Restricted by these conditions as well as by religious condemnation, art collections as we think of them today were non-existent. Books as well, though more useful than art collections, were fragile and heavy.

With art largely absent from the lives of the early colonists, early collections proceeded to be formed slowly along two trajectories: I) as personal libraries grew with the increasing arrival of ships and immigrants, library societies began to form. By extension the library societies would begin collecting instructive objects, forming small object collections'; and 2) the North American continent presented a new opportunity to add to the world's scientific knowledge. Those possessing a curious spirit collected biological and geological specimens to better observe and understand the new environment (Van Horne, 1985, sec. IO:II), creating scientific collections that would testify to the wonders of the new territory.

Before shedding the yoke of British imperialism, the early colonies embraced the English model for intellectual societies, which quickly multiplied across the US. ${ }^{2}$ Quickly in colonial history, groups of curious intellectuals sharing the same ideas created societies and combined their resources to create larger, more meaningful collections. By $1743^{3}$, the American Philosophical Society had been founded and had established a prototype for the American cabinet of

\footnotetext{
I. By 1740 the Library Company of Philadelphia began collecting objects. See Orosz (2002, p. I4).

2. Other early collecting societies include the American Philosophical Society, was founded in I769, the Massachusetts Historical Society in I79I, and the East India Marine Society in I799.

3. Coleman (1939, appendix X) gives the date of the founding of the American Philosophical Society as 1727 , but this date rather corresponds to the founding of the JUNTO, a private club founded by Benjamin Franklin (I706-I790) to discuss "Morals, Politics, or Natural Philosophy".
} 
curiosities. Like their European counterparts, these societies undertook scientific research and publication, but not public exhibition or access.(Alexander, I983, pp. 64-65; Coleman, 1939; Conn, 1998) Before the War for Independence, the most exotic or important specimens were often sent to Europe to enrich the cabinets there. Yet the collections that stayed were a good indication that Americans imagined themselves as a manifestation of the ideals of the Enlightenment. (Orosz, 2002) It is these collections that forge the way for the first public museums in the United States.

\section{Art in the Colonial Context}

At the moment when the British Colonies were established in North America, "art" in England had been conceived around elitist standards, lifestyles and vocabularies, making it intentionally exclusive to the wealthy classes. On the other hand, science and scientific collections offered the opportunity to escape ignorance, to improve humanity and raise one's (or a nation's) reputation. These ideals were naturally in step with the work necessary to establish new colonies: Man could escape the social status conferred by birth thanks to manual and intellectual labor, and not simply by riches.

This was buttressed by Protestant teachings. Even if scientific societies followed European models, the accentuation of science in the first collections in the American colonies was in direct relation to moral codes dominated by Puritans. According to them, science was useful and encouraged progress, while art was frivolous. "Only 'men of leisure' have the luxury to expend time for the acquisition of knowledge that has no further application." This observation implies that the "middling sort, who learn in order to advance their active pursuits in life," contribute more to society than their wealthier fellow citizens. ${ }^{4}$ (Brigham, I995, pp. I8-I9) The acquisition of useful knowledge was a moral and patriotic responsibility.

The hostility of Puritans toward the arts of Europe discouraged the profusion of religious images as a violation of the First Commandment (McCoubrey, I965, p. 3 and the first two sermons). Nudity in particular was condemned. Likewise, ornamental ostentation was suppressed by strictly utilitarian principals. In contrast, "Simplicity, Innocence, Industry, Temperance are Arts that lead to Tranquility" (Poor Richards Almanac, I786, cited in Neil, I975, p. 4) were the proper characteristics of Americans. These explicit words constitute the Puritanical roots of the exultation of utility before beauty in American culture and had profound repercussions on museums in the US.

\footnotetext{
4. On the significance of useful knowledge at that time, Brigham suggests this article, "On the Folly of Engaging in Trifling Studies," excerpt from the Columbian Magazine in the General Advertiser, August I4, I792.

5. See Kouwenhoven (1948) for a discussion of these principals.
} 
Under the strict conditions of the Protestant theocracy in $\mathrm{I} 7^{\text {th }}$ century, fine art in the US was limited almost exclusively to portraiture. Rather than perceived as a luxurious manifestation of ego as in European portraits of the wealthy, early American portraiture was permitted only if it met with the Puritan practice of introspection. Considered the nadir of European art (Silverman, 1976, p. I4), to the American Protestant, portraiture served as a memento mori if it were a true and humble likeness. The simple artistic styles with which these portraits were created came directly from the English and Dutch provincial styles of the time (McLanathan, I973, p. 36) and were limited to a "journeyman's" approach (McCoubrey, 1965, p. v), making early American portraiture a tradition of sober objectivity and brutal reality. Indeed, early portraitists were not considered "artists" or "painters" in the grand European traditions, but rather as "limners", amateurs who only sought to produce a basic resemblance to the sitter. By the $\mathrm{I}^{8^{\text {th }}}$ century, new generations of artists found the restrictions of portraiture frustrating, though they had significantly advanced its quality. Nevertheless, even after the American Revolution in the late $18^{\text {th }}$ century, artists complained about their low status in society. "I am fully sensible that the profession [painting], as it is generally practiced, is frivolous, little useful to society, and unworthy of a man who has talents for more serious pursuits." (John Trumbull, american artist, I789, cited in McCoubrey, 1965, p. 40)

While the religious sentiments had created distance between the art of Europe and the art of the Colonies, revolutionary sentiment required keeping a distance from cultural British models as well. ${ }^{6}$ The debate over the value of art versus science in the early US manifested principally as Colonist, often working class, pitted against the hedonistic, aristocratic British. The Europe that produced such fine arts was also the Europe that produced rigid class distinctions and sinful degeneracy, (Elson, I964, pp. 233-234) both of which the Colonists wished to escape. In seeking independence, the former colonies promoted American industry and the "useful arts", and sought to undermine British culture. (Nathans, 2003, p. I6) In October I774, the Articles of Association forbade all commerce with Great Britain until colonial disputes had been settled, citing specifically:

We will, in our several stations, encourage frugality, economy, and industry, and promote agriculture, arts and the manufactures of this country, especially that of wool; and will discountenance and discourage every species of extravagance and dissipation, especially all horse-racing, and all kinds of gaming, cock-fighting, exhibitions of shews, plays, and other expensive diversions. (The Continental Association, October 20, 1774, Art. 8)

Two elements are noteworthy in this excerpt: I) The singular mention of the wool industry to illustrate "arts and manufacture"; and 2) the comparison of theater and public entertainment to gambling and cock fighting. The former

6. $90 \%$ of respondents to first census conducted in the US indicated a British origin. See Key (197I, p. 63 ). 
reflects the religious and revolutionary sentiment of utility and art. And the latter reflects a long history of religious sentiment against theater and public entertainments as other art forms 7 . By forbidding theater as a product of British culture, Congress began to eradicate British influence and promote a national moral code: the American virtue in contrast to British luxury ${ }^{8}$. These sentiments also began to influence all forms of public exhibition, eventually impacting museums and their conception in the US.

In 1788 , the Articles of Association and their cultural strictures were abandoned for a national constitution.(Bartron, 2003, p. 86) Nevertheless, anti-theater sentiments persisted long after the birth of the nation in a number of the former colonies, especially those founded for religious reasons. (Nathans, pp. 47-48) In Pennsylvania, for example, the first capital of the new nation, Philadelphia, had served as a battlefield for pro-and anti-theater sentiments since the founding of the state's government in I682. (Bartron, 2003, p. 8I) Pennsylvania had been founded by Quakers, to whom seeing a play was "an offense against God" and incited men to "Disrespect, Cruelty, Debauchery and Sacrilege". (Nathans, 2003 , p. I4 et note 3) But, after independence from Britain, colonists were less susceptible to blind adherence to religious ideals. Social debates after the Declaration of Independence concentrated on personal liberty on which the principals of the new country had been founded. (Bartron, 2003)

As immigration increased, the entertainment industry flourished and religious influence began to further wane, introducing a transition from theocracy to democracy. (Shiffler, 1962, p. 218) British tastes and their cultural and social models, first rejected in a fit of revolutionary and anti-establishment fervor, would be resuscitated in a selective manner by national leaders who were resolved to create a new national identity (Anderson, I991, p. I29; Silverman, 1976) and in an effort to create an international reputation. (Nathans, note 38) Nevertheless the heritage of these laws continued to influence American entertainment forms during the decades to come, and the earliest museums had to delicately navigate the complex politics and social tastes.

\section{The First Museums of the US}

Much like in Europe, the first museums in the US arose from private cabinets of curiosity made public, placing useful education far above the arts. The first public collection to call itself a "Museum" in the Western Hemisphere was the Charleston Museum in South Carolina according to Coleman (1939, p. 6) and Alexander (1983, p. 65). It debuted as an extension of the Library Society of Charleston in I773, collecting articles and objects of learning relative to local history. The majority of its collections were destroyed during the Revolution.

\footnotetext{
7. See Bartron (2003) and Nathans (2003) for a longer discussion of anti-theater sentiment in the early US.

8. For more historical context, see also Silverman (1976), particularly chapters 25, 28, 42-46.
} 
After the Revolutionary War, it became incumbent on the young nation to demonstrate a lack of inferiority to European countries and their cultures. In the case of fine art, the US was ill-equipped and uninterested in rivaling European fine arts. But where it came to science, the exotic and unknown terrain of North America provided a splendid opportunity to rival Europe and establish a national reputation by radically expanding human knowledge. Whereas early colonists and voyagers might have sent back to Europe the best American specimens of flora and fauna, the new independent nation desired to forge its own spectacular collections (Peale et al., 1983, p. 446). The rise of science museums, scientific societies, as well as private and public collections is a direct result of this desire. (Bergeron, 2015, p. 48)

The first museum to claim the title "American" epitomized this attitude toward science and only relied on art as documentary. The short-lived I783-1784) American Musaeum of Pierre-Eugène du Simitière was an eclectic private collection of books, documents, portraits and landscapes, engravings of natural specimens, ethnographic objects, and biological specimens. Its brief life leaves little to emulate, but demonstrates a Protestant hierarchy of science and art.

It is only when Charles Willson Peale (I74I-I827), began to exhibit his own paintings as a public gallery in his own house around $\mathrm{I} 782$ and later as a scientific museum in 1786 that the nation finally had a museum of lasting impression and one that incorporated visual arts more fully. Nevertheless, the inclusion of art in a public museum necessitated some political agility on the part of Peale. Former soldier, revolutionary, self-taught artist and polymath, Peale was the perfect incarnation of an American entrepreneur to found what is often recognized as the first museum in the United States and to navigate the tricky and precarious politics and religious opinion of the time.

It is no coincidence that one of the key phrases employed by the Pennsylvanian legislature to justify the eventual abolition of longstanding anti-theater laws-"rational amusement"-was the same as that employed by Peale in his publicities to attract visitors.9 (Brigham, 1995, p. 19) The timing of his endeavor was perfect. The public was hungry for entertainment after war and religion had kept it scant. To navigate the complexity of the times, museum entertainment was advertised as education. His many efforts to navigate the complexity of the emerging American culture, still caught between politics and religion, created the orginal museum model that still finds traces in today's American museums.

Peale's first gallery, a sales gallery for his own work, was an unabashed commercial endeavor. Peale was well-placed and well-connected, his military past giving him access to important men. Taking advantage of these connections, of revolutionary sentiment and of a nation searching for heroes to venerate,

9. A term that is repeated as late as 1908 by Frederic A. Lucas, director of the Brooklyn Museum, in his speech given to the Staten Island Association of Arts and Sciences in 1908. See Genoways and Andrei (2008, p. 6o). 
Peale painted icons for a new world. (Alexander, 1983, ch. 3; Neil, 1975, p. 46) When Peale added to his personal picture gallery a "Repository of Natural Curiosities" (Brigham, 1996, p. 183) he founded the first popular museum (Sellers, 1980). This new Peale Museum distinguished itself by recognition of both science and religion. The portraits that had been the central focus of Peale's sales gallery were now placed high on the wall above natural specimens. As representations of humanity, rather than works of art, portraits were a means of exhibiting the highest creation of God "placed at the head of animal creation" (Hardie, I793, p. 230). The portraits, following Puritan tradition, were "good and loyal likenesses" (Ibid.) to demonstrate the paragon of progress (Neil, I975, p. 3I) - a level to which visitors could aspire. (Brigham, I995, p. 59) Favoring natural science over art allowed Peale to appeal to the proper moral and patriotic sympathies of the time, but it also allowed him to feature art within this approved context.

This public museum, like the original gallery, was a private enterprise. According to the Peale Papers (published family archives) the idea of a "museum" (a scientific focus) as opposed to a "gallery" (solely art) was suggested by a friend, who mentioned that he would prefer "seeing such articles of curiosity than any paintings whatever". (Peale, Miller, Hart, \& Appel, I983, p. 445) Following the lure of the more popular appeal of science was a strictly business decision geared toward earning more money. (Ibid. p. 337) Having trained as a leatherworker and cobbler, Peale developed an interest in enriching his natural collection with taxidermy specimens (Brigham, 1996), launching his museum in 1786 after he felt he had acquired enough.

Mr. Peale, ever desirous to please and entertain the Public, will make a part of his House a Repository for Natural Curiosities. The Public he hopes will thereby be gratified in the sight of many of the Wonderful Works of Nature which are now disclosed and but seldom seen. The several Articles will be classed and arranged according to their several species; and for the greater ease to the Curious, on each piece will be inscribed the place from whence it came, and the name of the Donor, unless forbid with such other information as may be necessary. (Peale et al., I983, p. 448)

It is important to note that Peale, from the beginning, attaches labels to every object in the museum, staying true to the proposed educational nature of his museum and perhaps anchoring an American museum perspective toward education above all. Indeed, in the young nation learning and freedom were mutually supportive ideas, though both were still colored by religious standards. Natural Philosophy, the study of nature, was the height of scientific learning and therefore encouraged American progress and continued independence. To highlight the serious scientific nature of his Museum, Peale published the fact that his museum followed the Linnaean System of scientific nomenclature (Alexander, I983, p. 62; Brigham, I995, p. 59). While the history of the 
Peale's Museum often cites his use of the Linnaean System, this is more likely a product of advertisement and desire rather than fact ${ }^{10}$.

One thing is certain: the effort to follow Linnaeus' System fully ascribes the Peale Museum into modernity. (Bergeron, 20I5, p. 52) Within a couple weeks of turning his venture toward science and education, The American Philosophical Society offered Peale a membership later granting him status as Conservator of the Society's own collection. ${ }^{\text {I }}$ (Orosz, 2002, p. 20) By centering his museum on science, and subordinating art to a supportive role, Peale sought to position himself and his museum at the center of political and religious thought that demanded the utility of knowledge, art, and even leisure.

As a Pennsylvanian, a Philadelphian, a Revolutionary, an artist and naturalist, Peale helped begin to give shape to the distinct American culture (Warner, I990, p. II9) for which Americans sought in the years following the revolution. His placement in Philadelphia, a de facto US capital for a while, ensured that the scope of his efforts and influence would be national. Peale established the trajectory for the museum in America for decades to come.

\section{National Identity Without National Funding}

The nation that took form after its independence was impoverished and politically precarious ${ }^{\mathrm{I}}$. Without large financial or military resources to establish a national identity, there was little room for the creation of capital or culture, or moreover the enjoyment of either. Nevertheless, it was evident to the founders that these were imperative to the survival of the new nation. The creation of myths and culture would help forge a national identity and a competitive international reputation on an image of fortitude and durability. (Neil, I975, p. I3) Nevertheless, even if such things were clearly important, there was hesitation by the federal government to finance museums which promoted these things.

Peale's museum once again provides an excellent example: Shortly after its founding, Peale's museum became famous. Peale announced his intention to make the museum national. He invited wealthy men to become trustees, counting among them many of the Founding Fathers of the nation. (Alexander, I983, p. 69) Thanks to his astute involvement of Thomas Jefferson, elected third President of the US in I80I, Peale was asked to sketch and document the exhumation of a newly discovered and fully articulated mastodon skeleton in the same year. (Pierpont, 2009; Semonin, 2000) The skeleton - the first fully articulated prehistoric in the world (Ibid. Pierpont, p. 9) - was exhibited

\footnotetext{
Io. According to his private journal cited in the Peale Papers (1983, pp.58I-2) Peale did not read Latin. (Peale., p. 525n) Moreover, many scientists found the taxonomy difficult and ambiguous. See Schofield (1989, pp. 25-27).

II. Bergeron (2015, p. 50), mentions this was a position previously held by Du Simitière from 1776 to $178 \mathrm{I}$.

I2. The US faced repeated wars: The War of I8I2, the Mexican American War (I846-I848), the American Civil War (I86I-I865) and the Hispanic American War (I898).
} 
at Peale's Museum, attracting thousands. The mastodon achieved a celebrity status and soon became a national symbol. (Ibid. Semonin)

Peale's Mastodon would also cause a great stir internationally. Jefferson, a respected naturalist, entered into a debate with the famous French scientist, George Louis LeClerc, comte de Buffon (I707-I788) about the implications of the mastodon on biological superiority. The Count had declared that the American continents were impotent and unable to produce anything other than fragile creatures. (Baltimore City Life Museums, I992; Jefferson, I853 [I78 I], pp. $45,48+$ ). The implications for a new nation and all inhabitants of North and South America were clear: From this perspective, all American species were destined to become degenerate and inferior to European species. Referencing the massive mastodon and its clear superiority in size over anything found on the European continent, Jefferson refuted these allegations championing the reputation and legitimacy of the new nation and its citizenry. (Ibid. Jefferson, pp. $42-80+$ ) From these debates, it is clear that science played an important role in national identity and reputation.

Encouraged by the success of the mastodon debates, Jefferson began planning the first US expedition into the western half of the continent. As well as adding to its burgeoning scientific reputation, the "Frontier" also posed an opportunity for the new nation to construct a mythology. In the context already devised by Peale, where the heroes of the Revolution and therefore paragons of human progress crowned galleries of natural specimens, Native Americans represented a stage of "uncivilized antiquity" that stood in contrast to this "progress". (Bennett, I995, p. 82; Brigham, I995, ch. 7; Conn, I998, pp. I2, 35 ) The "Noble Savage" and his archeological and ethnological artifacts became testaments to an "uncivilized savagery" (Poulot, 2000, pp. 5I-54) that God ordained to be eradicated by progress (Americans). This process of "patrimonialization, identification, valorization, appropriation and reinterpretation of ancient objects in a contemporary perspective permitted a society to project itself into the future." (Bergeron, 2010, p. I52, author's translation) In I804, the Lewis and Clark Expedition began its scientific exploration of the largely unknown territories of the west. It's collection of objects and specimens became the foundation and much of the justification for Manifest Destiny. At the end of the Lewis and Clark Expedition in I806, Peale's museum became the repository for these collections, firmly underscoring his museum's value to the nation. (Schofield, I989, p. 22)

To Peale, this seemed the perfect moment to obtain an official national title as well as national funds. But Jefferson refused to consider federal funding, whether the museum was "national" or not, (Alexander, 1983, p. 69; Schofield, I989, p. 22) even though Jefferson had secured federal financing for the exhumation of the mastodon as the "First Scientific Expedition of the Nation". (Pierpont, 2009) Perhaps uneasy because the patronage of culture in Europe was dominated by the aristocracy and the Church, it is also likely that Jefferson was unwilling to disrupt the delicate and emerging balance of state power 
under federalism, when he insisted on the fact that the US Constitution "left such encouragement to each State". (Jefferson, i8og)

The Peale Papers suggest an alternative and perhaps complementary reason for Jefferson's resistance to federal funding of museums-a reason that once again implicated the Puritans. In Pennsylvania, Quakers feared the interference of the government in education as something that would defy or contradict their strict religious teachings. Since the Colony's founding, education had been directed by religious standards and religious groups. An education managed by the government was considered almost heretical, and at minimum undesirable. Museums, modeled by Peale's and in order to avoid similar religious dissatisfaction on more social grounds, already evoked educational goals instead of frivolous entertainment. While this education was clearly supplementary to a larger educational system, government funding of museums may have been considered tantamount to government management of education. By this logic, educational institutions, including museums, remained separate from the government. (Peale et al., 1983, p. 583) The lack of government funding, meant that Peale and every other private museum holder was forced to constantly appeal to popular tastes in order to gain admissions. Many museums failed and others found their collections absorbed into travelling road shows of curiosities that were more concerned with spectacle than truth. ${ }^{13}$ It is a issue with which US museums continue to contend today.

\section{Conclusion}

Peale ultimately failed in his desire to obtain national funding to create a national museum, the likes of which would not be seen until half a century later with the opening of the Smithsonian and almost a century after that the founding of the National Gallery. But Peale did succeed in establishing an initial model of the American museum, one that still pervades the existing system, whether we know this history or not. Consider the American relationship to art, the role of education and funding in US Museums and the treatment of objects related to indigenous peoples.

In the United States, art, its practice, study, collection and exhibition continue to be colored by a view of frivolity. Those who are more "rational" or "useful" tend to be more highly regarded. Even as recently as 20I4, President Obama famously stated, "[F]olks can make a lot more, potentially, with skilled manufacturing or the trades than they might with an art history degree," revealing the lingering adherence to Puritan values in relationship to the arts in the US. By extension, art in the US continues to be the province of the wealthy. While there is a long history of how art museums came to dominate the museum

\footnotetext{
I3. For a longer treatment of the American museum history in relationship with travelling circuses, see Dennett (1997).
} 
model in the US, it does not begin until the industrial revolution in America massively expands the wealth in the US, creating a new aristocratic class.

Even in light of that, the focus of US museums continues to be their utility, wherein education is paramount. Certainly these efforts were emphasized by movements towards improved public education in museums in the r930s (McClellan, 2008, pp. I7I-I72) and I97os, but we see from this earlier history that it has always been imperative. Furthermore, the utility of museums continues to be linked to their financing. US museums continue to be privately funded institutions. While federal funding sources exist (National Endowment for the Arts, among others) competition for their limited funds is fierce, often won by larger, better funded museums, and is limited to the duration of special projects. State funding as well through humanities councils is so wide-spread that it often amounts to only a small percentage of a museum's total budget. These and funds from private foundations are almost always tied to goals measured by the number of people who benefit (find useful) from the project and so are frequently tied to educational activities.

Finally, there is one further area in which today's museums follow in the footsteps of the original US Museums. Collections comprising Native American objects, many of which were collected long ago, reflect the outdated view of Native Americans as a curiosity, and an "uncivilized" element of the "untouched" frontier. Certainly, there are museums that excel at re-examining such traditions, the National Museum of the American Indian, for example, but there are a remarkable number of museums which still imply that Native American cultures are all but extinct, referring to collections objects as "specimens" - implying non-human qualities - and "artifacts" - implying a dead culture. There is as well a tendency to refer to Native Americans as a homogenous culture, despite the vast and numerous nations that existed here before ever a European settler set foot. These small acts of miscomprehension perpetuate stereotypes and betray latent values that we can trace directly to the early politics of US museums.

Today's US museums might seem very similar to their European and British counterparts but there is a unique feel to museum practice and museum study. While cross cultural similarities may be evident, differences in character are harder to detect let alone comprehend. When this history is unfolded we begin to gain a greater understanding of the founding characteristics of our field, some of which continue to have impact. Moreover, more knowledgeable of the past, we can better plan our path into the future.

\section{References}

Alexander, E. P. (1983). Museum Masters: Their Museums and Their Influence. Nashville, TN: American Association for State and Local History. 
Anderson, B. R. O. G. (I99I). Imagined Communities: Reflections on the Origin and Spread of Nationalism. New York: Verso.

Baltimore City Life Museums. (1992). Mermaids, Mummies, and Mastodons: The Emergence of the American Museum. Washington, DC: American Association of Museums; Baltimore City Life Museums.

Bartron, M. (2003). "The Tenter-Hooks of Temptation”: The Debate Over Theatre in Post-Revolutionary America The Gettysburg Historical Journal, 2(I, Art. 8), 75-I08.

Bennett, T. (1995). The Birth of the Museum History, Theory, Politics. London: Routledge.

Bergeron, Y. (20I0). Le rôle des musées dans la construction des identités nationales. In L. Turgeon, \& A. Charbonneau (Eds.), Patrimoines et identités en Amérique française (pp. I49-I69). Québec: Les Presses de l'Université Laval.

Bergeron, Y. (2015). Musées et muséologie au Québec : Essais d'interprétation. (Habilitation à diriger des recherches [HDR] Habilitation à diriger des recherches (HDR)), Paris: Université de Paris I - Panthéon-Sorbonne.

Brigham, D. R. (1995). Public Culture in the Early Republic: Peale's Museum and its Audience. Washington, D.C.: Smithsonian Institution Press.

Brigham, D. R. (1996). "Ask the Beasts, and They Shall Teach Thee": The Human Lessons of Charles Willson Peale's Natural History Displays. The Huntington Library Quarterly, I83-206.

Coleman, L. V. (1939). The Museum in America: A Critical Study. Washington, D.C.: The American Association of Museums.

Conn, S. (1998). Museums and American Intellectual Life: 1876-1926. Chicago: University of Chicago Press.

The Continental Association, October 20, 1774. (I774). Philadelphia Retrieved from http://www.loc.gov/teachers/classroommaterials/presentationsandactivities/presentations/timeline/amrev/rebelln/assoc.html.

Dennett, A. S. (1997). Weird and Wonderful: The Dime Museum in America. New York: New York University Press.

Elson, R. M. (I964). Guardians of Tradition: American Schoolbooks of the Nineteenth Century. Lincoln: University of Nebraska Press.

Genoways, H. H., \& Andrei, M. A. (2008). Museum Origins : Readings in Early Museum History and Philosophy. Walnut Creek, CA: Left Coast Press.

Hardie, J. (I793). The Philadelphia Directory and Register: Containing the Names, Occupations, and Places of Abode of the Citizens ... a Register of the Executive, Legislative, and Judicial Magistrates of the United States and the State of Pennsylvania ... Also, an Account of the Different Societies, Charitable and 
Literary Institutions, with the Names of Their Present Officers. Philadelphia: Printed for the author, by T. Dodson.

Jefferson, T. (I774, 20 October). The Association Entered into by the Continental Congress on Behalf of all the Colonies ("The Articles of Association"). Thomas Jefferson Papers, Series I. General Correspondance, I65I-I827. United States Library of Congress, Philadelphia.

Jefferson, T. (I853 [I78I]). Notes on the State of Virginia. Richmond, VA: J.W. Randolph.

Jefferson, T. (I903). Letter from Jefferson to Doctor Maese, January I5, I809. In A. A. Lipscomb \& A. E. Bergh (Eds.), The Writings of Thomas Jefferson (Vol. I2, pp. 230-232). Washington, D.C.: Issued under the auspices of the Thomas Jefferson memorial Association of the United States.

Key, A. F. (I97I). Beyond Four Walls: The Origins and Development of Canadian Museums. Toronto: McClelland and Stewart.

Kouwenhoven, J. A. (1948). Made in America: The Arts in Modern Civilization. Garden City, NJ: Doubleday.

Lucas, F. A. (I908). Purposes and Aims of Modern Museums: Proceedings of the Staten Island Association of Arts and Sciences, 2: II9-I24. In H. H. Genoways, \& M. A. Andrei (Eds.), Museum Origins: Readings in Early Museum History and Philosophy (pp. 57-64). New York, NY: Routledge.

McClellan, A. (2008). The Art Museum from Boullée to Bilbao. Berkeley, CA: University of California Press.

McCoubrey, J. W. (1965). American Art, 1700-1960: Sources and Documents. Englewood Cliffs, NJ: Prentice-Hall.

McLanathan, R. B. K. (1973). Art in America: A Brief History. New York: Harcourt Brace Jovanovich.

Nathans, H. S. (2003). Early American Theatre from the Revolution to Thomas Jefferson: Into the Hands of the People. Cambridge, UK: Cambridge University Press.

Neil, J. M. (1975). Toward a National Taste: America's Quest for Aesthetic Independence. Honolulu: University Press of Hawaii.

Orosz, J. J. (2002). Curators and Culture: The Museum Movement in America, 17401870. Tuscaloosa, AL: University of Alabama Press.

Peale, C. W., Miller, L. B., Hart, S., \& Appel, T. A. (1983). The Selected Papers of Charles Willson Peale and his Family. Artist in Revolutionary America, 17351791 (L. B. Miller Ed. Vol. I). New Haven, CT: Published for the National Portrait Gallery, Smithsonian Institution, by Yale University Press. 
Pierpont, R. (2009). Peale's Barber Farm Mastodon Exhumation Site. (NPS Form OMB No. I024-оог8). Washington, D.C. Retrieved from http://www. nps.gov/nr/feature/weekly_features/2009/MastodonExhumationSite.pdf.

Poulot, D. (2000). Les Lumières. Paris: Presses universitaires de France.

Schofield, R. E. (I989). The Science Education of an Enlightened Entrepreneur: Charles Willson Peale and His Philadelphia Museum, I784-I827. American Studies, 2I-40.

Semonin, P. (2000). American Monster: How the Nation's First Prehistoric Creature Became a Symbol of National Identity. New York: NYU Press.

Silverman, K. (1976). A Cultural History of the American Revolution: Painting, Music, Literature, and the Theatre in the Colonies and the United States from the Treaty of Paris to the Inauguration of George Washington, 1763-1789. New York: T.Y. Crowell.

Van Horne, J. C. c. (1985). Pierre Eugene Du Simitière: His American Museum 200 Years After. Philadelphia: Library Company of Philadelphia. 